\title{
Sami Identity and Preferred Futures: Experiences among Youth in Finnmark and Trøndelag, Norway
}

\author{
Line Mathisen \\ Norut Northern Research Institute, Troms $\varnothing$, Norway \\ Espen Carlsson \\ Trøndelag R \& D Institute, Norway \\ Niels Arvid Sletter $\varnothing \mathrm{d}$ \\ Trøndelag R \& D Institute, Norway
}

\begin{abstract}
Depopulation is a growing concern in core Sami areas in Norway, and the loss of productive young people is a particular concern for rural regions. Yet new industrial developments are debated due to the impact on traditional identitydeveloping practices such as reindeer herding. The objective of this article is to gain knowledge about how Sami youth identity shape their decisions to stay or return to their home place and how they envision their opportunities for employment. This qualitative study investigated how Sami youth experience Sami identity as a determinant of educational, occupational, and housing preferences. Data was collected through interviews with fourteen Sami youth from three different types of Sami communities in Norway-Guovdageaidnu (Kautokeino), located in the core Sami area in Inner Finnmark, with a strong reindeer based economy and Sami as the first language; Mátta-Várjjat (Sør-Varanger) and Porsángu (Porsanger) in coastal Finnmark; and the southern Sami areas based around Snåase (Snåsa) in North Trøndelag. The informants from the three communities were university and college students, high school pupils, and apprentices. The study's theoretical framework and analysis is inspired by the theories and applications of the life mode perspective, combined with perspectives of cultural identity, locale, landscape, and global "sense of place." The findings suggests that life modes that signify or enable salient Sami values influence how Sami youth reflect on their Sami identity and envision opportunities. Furthermore, the findings show that different life modes influence Sami youth identity development through providing opportunities for new expressions of a Sami identity.
\end{abstract}

The Northern Review 45 (2017): 113-139

Published by Yukon College, Whitehorse, Canada 


\section{Introduction and Background}

Research shows that Sami youth have a desire to contribute towards future development of Sami culture (Pedersen \& Viken, 2009). However, less is known about the relationship between how they experience their ethnic identity and how they perceive opportunities for future work and housing in Sápmi (Aure, Abelsen, \& Nilsen, 2012; Eikeland, 2009). Inspired by the theory of life modes and researchers' applications of this perspective in concrete investigations worldwide, as well as by the concept of "sense of place" (Højrup, 1996; Massey, 1991), this article investigates how Sami youth experience Sami identity, educational and occupational preferences, and housing. The key analytical concepts are identity and life modes.

The development of an ethnic identity is most properly described as a process of construction over time (Phinney, 1990; Phinney \& Ong, 2007) due to the combination of experiences and actions of the individual. This includes gaining knowledge and understanding of the specific characteristics defining in-groups as well as a sense of belonging to, and socio-cultural affiliation with, the ethnic group in focus. In-group is a concept defining the socio-cultural qualities and traits to which a person psychologically identifies as being a member. An in-group therefore often coincides with the contextually defined life mode experienced by the person. Yet a life mode could encompass several in-groups or ethnic groups, and the members of an in-group could be scattered over several life-modes as is, in fact, the situation for the Sami people in Norway. Our point is that an ethnic identity will have a very long-term horizon of change, but the life-mode identity could change in the short term and may therefore also be viewed as a sudden event.

The Sami are Indigenous peoples of the Arctic regions of Norway, Finland, Sweden, and Russia; however, the core Sami areas are in the north of Norway where the Sami are the majority in Guovdageaidnu (Kautokeino) and Kárásjohka (Karasjok) municipalities. They also have substantial populations in Deatnu (Tana) and Unjárgga (Nesseby) (see Figure 1). ${ }^{1}$ The core Sami areas in the North have a high number of Sami

speaking inhabitants; there are also several Sami institutions and strong ethnic support. This differs from the coastal communities in Finnmark where there are fewer Sami speaking inhabitants, few institutions, and a generally weak ethnic support. Further, the Sami people can be divided into three main language groups; Northern Sami dominates in Finnmark and Troms, Lule Sami is spoken in parts of Nordland, and South Sami 
in Mid-Norway. In the south, there are fewer Sami, most of whom live in smaller enclaves or communities. The southern Sami territory reaches over large areas in the middle part of Norway and Sweden. South Sami people inhabit, for instance, four counties in Norway: Hedmark, Southand North Trøndelag, and Nordland, with the municipalities Røros, Snåsa, and Hattfjelldal as core areas (Johansen, 2006; Saemien Sijte, 2017). ${ }^{2}$ It is difficult to confirm the exact population, but sources assume the total number of South Sami in Norway and Sweden to be approximately 2,000 (Johansen, 2006; Saemien Sijte, 2017). Hence, the density of South Sami is sparse. Further the Sami Parliament, which represents the Sami people, is located in Guovdageaidnu (Kautokeino), Finnmark. To be registered, a person is not required to live in a core Sami area, but must speak Sami or have parents, grandparents, or great-grandparents who spoke Sami, or have parents who are registered (Selle, Semb, Strømsnes, \& Nordø, 2015).

Currently, due to migration, Sami people increasingly live and work in bigger cities where the majority of the population is Norwegian (Falch \& Selle, 2016). As more Sami youth move to larger cities, their Sami identity is increasingly under pressure, in particular if they do not speak the language. This can result in an increased potential for developing urban expressions of a Sami identity (Kielland, 2017; Nyseth \& Pedersen, 2014; Selle et al., 2015), thus adding layers to their identity that they switch between depending on situation and context. While this can challenge preservation and development of a Sami identity, the Sami who live and work in cities actively use connections to their homeland to preserve their Sami identity (Selle et al., 2015). One way to actively communicate their connections to homeland is to register with the Sami Parliament. This means that the Sami can have a dual citizenship, hence be both Sami and Norwegian at the same time (Selle, Semb, \& Strømsnes, 2013; Selle et al., 2015). Furthermore, those Sami who have a dual citizenship feel a stronger sense of community with their ethnic group, and with a more solid connection to their homeland, than those who only have Norwegian citizenship (Selle et al., 2013).

The connection between identity and homeland highlights the strong importance and position of reindeer herding as a territorial Sami practice. The practice of reindeer herding is central to the Sami culture, and the largest pastoral region is in Finnmark, in North Norway, where almost the whole county is defined as a reindeer herding area (Johnsen, 2016). Reindeer herding is suggested to be an important identity marker and continuity carrier for Sami language and culture in the South Sami area, where the majority of the Sami population engage in reindeer herding 


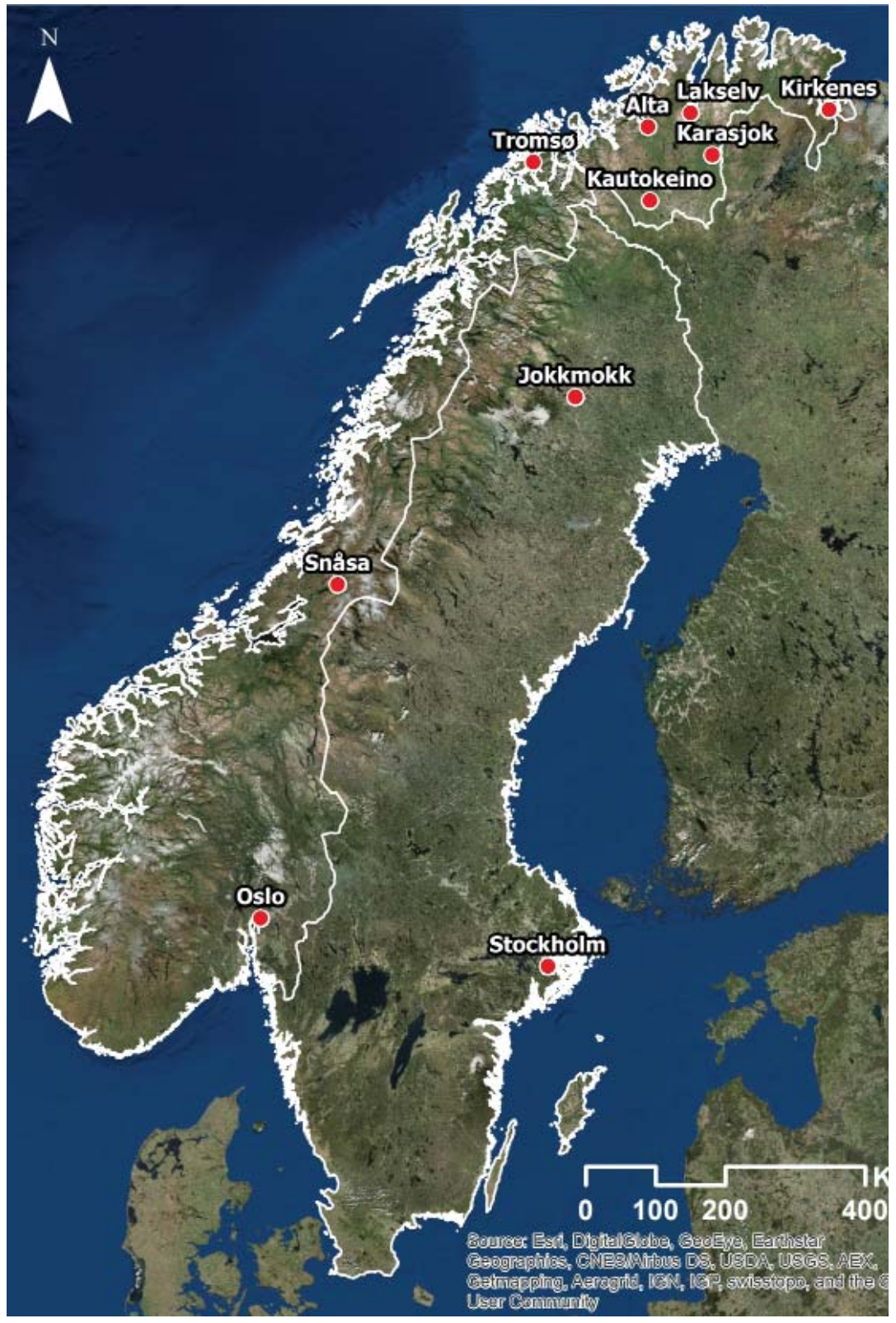

Figure 1. Map of Norway, Sweden, and Finland showing important places for the Sami people 
(Hilmo, 2012; Johansen, 2006; NOU, 20077). Despite Finnmark being the largest pastoral region, with the number of reindeer and reindeer herders in the North exceeding the numbers from the South, the majority of the Sami population in the North work in the public and private sector. For instance, employment in social services, education, and public administration in Guovdageaidnu (Kautokeino) is about $50 \%$ percent of total employment in this community. According to Hilmo (2012), 504 people are involved in reindeer herding in the South, while 884 people are in the Sami electoral register. In the northern part of Sápmi, 2,508 people are associated with reindeer herding, whereas 11,150 are in the Sami register. Hence, the Sami percentage involved with reindeer herding in the southern region is $57 \%$ compared to $22 \%$ in the northern area (Hilmo, 2012). Yet, few are fully employed as reindeer herders in either area; reindeer herding constitutes only about $3 \%$ of the employment in the North (E. Angell, Gaski, Lie, \& Nygaard, 2014). This reveals an important structural variance in the two geographical contexts (Hilmo, 2012, p. 17). In addition, this clearly documents a significant structural difference in the identity-generating cultural contexts. In this respect, there can be important differences due to variations in contextual characteristics of the northern and the southern Sápmi areas in Norway. To reveal, describe, and explain how this causality works, it is necessary, to some extent, to understand why and how contextual differences generate variations in Sami identity, and how these form a diversity of Sami youth values and preferences.

In general, youth who feel they belong to an ethnic group engage in cultural practices and behaviours to explore and strengthen their ethnic identity (Phinney, 1990). Through shared values, culture, and language, a feeling of kinship or community rooted in important values, time, practices, and place is established (Phinney, 2005; Selle et al., 2013). An ethnic group identity and territorial belonging can build, and strengthen, a collective identity and an individual's self-assurance and resilience (Angell, 2009; Nystad, 2016). It follows that Sami youth who see themselves as belonging to an ethnic group are more likely to use salient cultural identity markers as a guide to important life choices (Phinney \& Ong, 2007). However, ethnic groups' embeddedness in regional, national, and global contexts suggests increased diversity in terms of values (Hovland, 1999), and Sami youth are experiencing continuous impacts from a variety of socio-cultural settings. Ashkari (2005) shows significant connections between contextual understanding, cultural frameworks, ethnicity, and identity among Sami youth in Finnmark, in suggesting that identity is 
relational and that the meaning of identity can change in response to variables present in social interactions and context. According to Nisbett et al. (2001), social differences among different cultures not only affect beliefs about specific aspects in the world, but even, for example, "the nature of their cognitive processes-the ways by which they know the world" (Nisbett, 2001, p. 291). This highlights the importance of the symbiotic relations between individual choices related to identity and recognition amongst peers to manage identity variations and to create cohesion (Ashkari 2005). These variables have a wide range of variation producing a diversity of competing Sami identity markers. This may result in conflicting preferences and opposing values experienced in personal, clan, and family life and perceived ethnic group membership. Accordingly, there will always be identity challenges influencing the choice of education, occupation, and place of residence. Further, the connection of Sami youth to the past through traditional Sami heritage, values, and language, and to the future through their choice of education and work, makes them important indicators for understanding and responding to current and future developments of, and in, Sami communities. As indicators, their thoughts about the future Sápmi can provide useful scenario knowledge for planning and development processes in Sami communities (Eckersley, 1999).

The increased focus on contextual changes due to industry development processes in Sápmi adds relevance to this study because, although such processes are viewed as necessary to increase employment, they are viewed as a threat to the economic and cultural basis for a Sami life mode (Sørlie \& Broderstad, 2011). Such threats include predator protection bound by international conventions; the development of nature tourism; and allocations of areas to holiday housing, infrastructure, and realizations of sports events. However, like other rural areas in many parts of northern Norway, Sami areas, and especially core Sami areas, need new development to enable growth and increase place attractiveness (E. Angell, Aure, Lie, Nygaard, \& Ringholm, 2012). In particular, Sami youth, and especially females, are increasingly moving to cities for educational or occupational reasons, and many of them are likely to settle down in the cities to which they move (Broderstad, 2012; Sørlie \& Broderstad, 2011). Yet, while national and sometimes local articulations highlight the need for new developments based on articulations of future work possibilities and local or regional growth, i.e., resource intensive industries, Sami communities bring forth the long-term value-decreasing potential that such industries have on traditional Sami ways of living, in particular in 
relation to reindeer pasture land and fisheries areas (Josefsen, Søreng, \& Selle, 2016). For instance, through history, the life mode of reindeer herding with its relation to nature, landscape, and culture, has resulted in strong powers in the Norwegian constitution, entailing territorial use and rights that differentiate the Sami from the Norwegians, thus contributing toward a collective Sami identity (Johnsen, 2016).

This article will explore similarities and differences, dominant life modes, varying contextual attributes, and the resulting perceived Sami identity in two Norwegian cases, one northern and one southern. The aim of the article is twofold. The first is to illuminate the contemporary cultural reality of being a young Sami in Finnmark and Trøndelag, with special reference to issues such as identity/self-perception, perceived and desired opportunities for future work, and preferences for education and occupational paths. The second purpose is to use the life mode approach to analyze and discuss the findings in terms of future opportunities and challenges to the development of Sami communities. The following questions are essential:

1. How do Sami youth experience and articulate identity?

2. How do they perceive possibilities and preferences for education, occupation, work, housing, and place of residence?

3. How can a life-mode approach explain the generation of preferences and the diversity of forms expressed in the young Sami identities of today?

In the next section, we present the theoretical perspectives that the empirical analysis rests upon. The following section presents the data sample and procedures followed during the data gathering. The subsequent sections present methodological issues, findings and analysis, and the conclusion.

\section{Theoretical Perspectives On Life Modes and Sami Identity}

The life-mode concept (Højrup, 1996; 2014) is a perspective in which an individual's actions and preferences gain meaning when understood in a wholistic way. This perspective encompasses a culturally defined and adapted life context and its internal and external conditions. According to Højrup (2013; 2014), four different life modes are involved in one total economic process: the life mode of the self-employed, the life mode of investors, the life mode of career professionals, and the life mode of wage earners (Højrup, 2014). The modes have different presuppositions and an individual's perception of each life mode is coloured by that individual's value base (Højrup, 2014). For instance, the life mode of the 
self-employed is viewed as a socio-cultural embedded and independent way of living comparable to art and various forms of entrepreneurship. Further, the life modes of investors and career professionals are enabled by diversification in terms of type and number of unique and individual development possibilities, and the life mode of wage earners is economically conditioned and regulated through supply and demand in a labour market. The particular life mode's value base means that life mode preferences resonate with the way individuals (desire to) live their lives and thereby how they imagine life to be in the future. For example, the self-employed life mode is suggested to have a different values base than that of a wage earner-that is, a relational and ideological values base (Høst, 2010). In addition, this life mode suggests a traditional and gendered division where a wage-earning life mode becomes one of support, e.g., the female in the role of traditional wage earner such as teacher and nurse, which still leaves enough leisure time to take care of a family (Hørup, 2003; Jakobsen, Gonäs, \& Karlsson, 2006).

The different life modes are enabled and supported by the contextual factors that shape identity development and structure interactions, which creates traditions and forms ideological patterns common to individuals who follow them. In research, life-mode analysis can contribute to deeper insights into structures shaping patterns of value creation; what they are, how they condition life and work and with which effects (Hørup, 2003). For instance, Riseth (2006, p. 549) and Åhren (2008) demonstrated fruitful applications of the life mode approach of Højrup (2003) to analyze and understand reindeer herding as an independent life mode. Their findings resonate with the findings of Bergquist (2004) and Nordin (2007). The latter applies the life-mode approach in analyzing reindeer herding and its economic adaptation and states that: "A life mode is lived by a population, the existential conditions for the actual life mode is the actual population's cultural living conditions" (our translation).

The life mode perspective, combined with theories of cultural identity, makes a valuable approach to understand and explain the significance of how and why "reindeer herding" has become a prominent ethnic marker and is linked to articulations of a "true" Sami identity (Blix, Hamran, \& Normann, 2013). This life mode incorporates identity to a larger extent than other life modes in Sápmi, because it melts into the materially based family nexus of experiencing the individual Sami identity and a common Sami attachment and belonging. Simultaneously, a life mode approach represents a practical perspective to describe a way of living and offers a theoretical tool for analyzing and revealing the real structure or traits 
of important living conditions, generating important identity markers. A life-mode analysis contributes to uncovering essential contrasts and similarities between ethnic groups and populations (Blix et al., 2013) in terms of values and resulting preferences for education, housing, and work-i.e., dreams and expectations for the future. Therefore, this perspective is relevant to understanding how the Sami identity, with its corresponding values, norms, preferences, and boundaries, emerges and develops among young Sami people in the two areas of study.

The life-mode approach is linked to the use of practices in time and space/place (Høst, 2010), and it can be suggested that the life mode of reindeer herding has a link to Sami youth identity development through the historic nomadic understandings of place (Twigger-Ross \& Uzzell, 1996). Thus, disruption of reindeer herding can be perceived as a disruption of place with its spiritual, economic, social, and cultural consequences - and therefore a threat to the Sami identity. Place is a complex geographical idea, but has traditionally had three main meanings (Castree, 2003, p. 167): 1) location, i.e., a specific point on the earth surface; 2) sense of place, i.e., the subjective feelings on places, including the role of places in people's individual and group identity; and 3) locale-a setting and scale for people's actions and interactions on a daily basis. Werlen argues that locales have five main effects, as they

1. structure people's life-paths in space and time inasmuch as they provide the main nodes through which life must flow;

2. can have effect on other people's life-paths;

3. provide the arena within which interaction with other people takes place; thus locales are the sites where class conflicts take place and the main context in which experience about the world is gathered and common awareness engendered;

4. provide the activity structure of everyday routine;

5. are the major sites for the processes of socialization, from birth to death; they represent places in which collective modes of behaviour are learned.

Hence, places, understood as locales, have great impact on people's lives and identity development. They are structures and settings of (inter) action that have a determining impact on life paths, or as particular time-space patterns. In addition, identities meet in places where they are contested and shaped by the place materiality and experiences, including constellations of social relations, giving a feeling of rootedness and life 
meaning (Massey, 1991; 2013). Thus, the meanings attributed to places, particularly in core Sami areas, are constructed through language, family traditions, and culture-bearing activities (Arntsen, 2013; Bishop \& Willis, 2014). The meaning and the significance of identity and place are rooted in relational and dynamic expressions of the Sami identity, and identity markers are strengthened through local practices (life modes) deeply rooted in language and culture, which connect the past and present through a feeling of collectiveness/groupness that differentiates the Sami from the Norwegians (J. Valkonen \& Valkonen, 2014; S. Valkonen, 2014).

By studying young Sami identities though a life-mode perspective we can interpret stories depicting and connecting Sami identity and belonging. This highlights reindeer herding because it expresses who they (historically) are and want to be as part of a cultural, ethnic community and emerging story. For instance, reindeer herding calls into being political, economic, ecological, social, and cultural dimensions of Sami life in ways that influence everyday practices, youth identity development, and possible ways of living, particularly in core Sami areas (Bjørklund, 2016; Heikkilä, 2006). Further, reindeer herding represents core Sami values and vital living conditions (is life-mode situating), incorporating ecological, cultural, and political ways of life pertaining to a "real Sami identity," which entails feelings of belonging to a homeland (YuvalDavis, 2006). Sami youth interpretations and meaning-making are culturally conditioned and defined by material and discursive (linguistic) dimensions conditioning and presupposing each other (Setten, 2013, p. 93). The material dimension of a landscape is the totality of earth, trees, animals, housing, and roads-all the physical aspects you are able to observe in the surroundings. These attributes are not finally given; they get their discursive significance, meaning, and value in a social and cultural context, or, put in another way, in the actual life modes and practices of groups of individuals and groups of people. (Johnsen, 2016; Wollan, 2004, p. 49). We conclude this theoretical discussion by claiming that belonging and identity are integrated and represent the two sides of the coin of the independent life mode represented by reindeer herding.

\section{Study Design and Method}

The study has a qualitative research design. As Janesick (2003, p. 46) has argued, qualitative research has similarities to choreography: a planned direction of movements in a specific pace and an ability for improvisation and crystallization-incorporation of various disciplines as part of the research design - at the same time. In essence, a good qualitative research 
design turns on the use of a set of procedures that simultaneously are open ended and rigorous, and does justice to the complexity of the social setting that is studied.

Our research is inspired by prior research and theory related to the overall theme of Sami youth identity, but may to some degree be related to the grounded theory tradition, defined as "the discovery of theory from data systematically obtained from social research" (Glaser \& Strauss, 1967, pp. 2-3). This is contrasted "with theory generated by ontological deduction from a priori assumptions" (Glaser \& Strauss, 1967). The theoretical framework presented in part two of this article is the result of a dynamic interplay between concepts and perspectives in prior studies underlying the analysis, and themes/paths discovered during data gathering and analysis. Accordingly, it has a light semi-grounded side embedded in the analytical design (see for example Benyon, Smyth, O'Neill, McCall, \& Carroll, 2006).

In April-June 2015 we carried out fourteen interviews with young people from three different types of Sami communities: Guovdageaidnu (Kautokeino), located in the core Sami area in Inner Finnmark with a strong reindeer based economy and where Sami is the first language, MáttaVárjjat (Sør-Varanger) and Porsángu (Porsanger) in coastal Finnmark; and the southern Sami areas based around Snåase (Snåsa) in North Trøndelag. The informants from the three communities were university and college students, high school pupils, and apprentices (Table 1).

Guovdageaidnu (Kautokeino) and Snåase (Snåsa) are Sami institutional nodes in the two geographical areas: Important Sami institutions in Guovdageaidnu (Kautokeino) are the Sami University College, the upper secondary high school, include the Sami National Theatre Beaivváš. Snåase (Snåsa) in the south has a Sami school and the Seamien Sijte, the South Sami Museum and Cultural Centre that houses the public reindeer management, the Sami cultural heritage board, Duodjeinstituhtta and "Nord-Trøndelag reinsamelag," Sami Radio, and a South Sami church service.

During the process of recruiting informants, we experienced unexpected difficulties. While a key contact at Saemien Sijte, Snåase (Snåsa), helped to obtain contact information of fifteen potential South Sami youth informants in Trøndelag, making appointment for interviews proved challenging. The plan was to do group interviews with youth at Snåase (Snåsa), but this was not possible due to lack of interest or motivation. Furthermore, it was problematic to carry through arranged interviews because informants did not respond to phone calls at times 
agreed upon earlier. The bias is difficult to uncover and estimate because the lapse of informants was not systematically due to certain parameters, but randomly produced without any apparent causes.

In Finnmark, the University of Tromsø, the Arctic University of Norway (UiT), and contacts at the Norwegian Saami Association and the upper secondary school in Guovdageaidnu (Kautokeino) assisted in the recruitment process. In spite of this assistance, several of the young people outside Sami core areas did not respond or told us they did not want to participate in an interview. For instance, one potential informant in Finnmark said: "I guess I am Sami, my mother/father/grandmother are Sami's, but I don't feel like participating." Many of the young people who did not want to participate in Finnmark had only one Sami parent.

The interviews were semi-structured and open-ended. We followed an interview guide where the informants were asked about their Sami identity; why they have chosen the type of education or focus in their study; their thoughts about the future, family, and place; and how they envision themselves in their home place in the future. We interviewed eight females and six males between 18 and 31 years of age. Four of the informants in Finnmark have Sami parents on both sides and are native speakers, while the rest speak Sami as a second language. As far as we know from the interviews, all informants in Trøndelag have South Sami parents on both sides. Nine of the interviews were with individuals, while five informants in Finnmark participated in a group interview. The number of participants was sufficient to create good dynamics and group discussions. The participants were not friends, but knew about each other, thus this could have influenced the openness of the discussion (Cameron, 2005). One of the advantages of interviewing by telephone is the extended access to informants, for instance spread in wide geographical areas and hard to reach in other respects. The disadvantages of interviews by telephone include the asynchronous communication of place, hence a reduction of social cues, a view of the situation in which the informant is situated, and a reduced ability to create a good interview rapport (Opdenakker, 2006). The latter is an advantage of face-to-face interviews. However, doing telephone interviews were a precondition for accessing some of the informants in this project, and we got the impression that the interviewees answered our questions openly and honestly. Two researchers participated in every interview, both by telephone and face to face. The dynamics between the participants and the researchers in the group interview were good, with the interviewers taking turns in talking and the researchers guiding the conversations. The interviews were tape- 
recorded, transcribed, sorted thematically in an interview protocol, and distributed amongst the researchers for comparison and analysis.

Table 1. Overview of informants

\begin{tabular}{lcc}
\hline Name (pseudonym) & Occupational status & Area \\
\hline Per & male student & North Sápmi \\
Hanna & female student & North Sápmi \\
Anna & female student & North Sápmi \\
Jenny & female student & North Sápmi \\
John & male student & North Sápmi \\
Mikkel & male student & North Sápmi \\
Aslak & male student & North Sápmi \\
Morten & male student & North Sápmi \\
Elen & female student & North Sápmi \\
Ask & male apprentice & South Sápmi \\
Brita & female student & South Sápmi \\
Carine & female student & South Sápmi \\
Dagmar & female teacher & South Sápmi \\
Embla & female, finished high- & South Sápmi \\
\hline
\end{tabular}

\section{Findings and Analysis}

\section{Sami Youth Experience and Articulation of Identity}

When we state identity as performance, it is rooted in dramaturgical theory, as part of the paradigm of symbolic interactionism (Goffman, 1978). In line with such a perspective, social interaction is a theatrical performance, metaphorically speaking, and all performances are addressed to an audience (the Sami clansmen as well as outsiders), designed to confirm particular images embedded in an overall cultural practice, at the same time strengthening the identity practice itself or acknowledging a community (life mode) of a certain identity practice. The cultural identity expressed through a genuine performance can be given intentionally (strategically as a chosen identity marker) or given off unintentionally (part of a non-reflexive authentic-being as a Sami). An identity practice enables a multiple number of possible recognized identity performances expressed through the various life modes of the Sami. 
The interviews showed that Sami youth experience and articulate their identity through social relations and through nature and landscape practices. In general, the strength and practice of their Sami identity depend on language skills and social-material relations. Anna says, "When you live in a Sami culture your feeling of belonging increases." This entails language skills and physical proximity to everyday practices of traditional and acknowledged Sami identity markers. However, the different contexts investigated indicate similarities and differences in the experience of the Sami identity. For instance, in Finnmark, a sense of belonging to an ethnic group can be strong outside of the core Sami areas, as Jenny illustrates: "I have always felt Sami, even though none of my parents speak the language and I grew up outside the core Sami areas." Moreover, in families with multiple children, some of the children may have a strong experience of their Sami identity, while others may think of themselves as Norwegians, as Morten says: "it's a bit funny, I think, that I feel Sami and my sister feels Norwegian when we had the same childhood." He continues, "and I dress up in a traditional Sami costume while she dresses up in a dress." Similarly, Jenny says, "my mother spoke a lot about her Sami childhood and this greatly influenced my feeling of being a Sami."

While a Sami identity can be strongly felt in places with a majority Norwegian culture, the young Sami who do not speak the language well feel inferior to the Sami who do speak the language. John says that "in my hometown some people are more Sami than others," while Jenny says that "some places are more Sami than others," both referring to feeling less Sami when encountering individuals well-articulated in the Sami language, and visiting family or friends in core Sami areas (e.g., see Bjørklund, 2016). Hence, while the youth's identity development linked to family stories thus strengthens with social relations, a difference in contextual understandings can also instill different development paths of identity development (Ashkari, 2005). This also entails meanings about resource based industries. While the Sami youth from the North have experiences of mining, those from the south have experienced few examples of industrial interventions. There are several examples of plans and licensing applications for intervention in the southern region, both regarding mining and wind power, but this is primarily outside the "Snåase context." This can be one reason for the difficulties that South Sami youth have in expressing their thoughts on future industrial development in this area. Thus, their conscious thoughts are primarily to safeguard the southern Sami culture and identity through educational, vocational, and 
residential choices that make it possible to assist in, and attend to, family traditions and activity.

Sami Youth Perceived Possibilities and Preferences for Education, Work, and Place of Residence

For the youth wishing to return to their hometown or region, their dreams about work in Sápmi are linked to working with issues that allow them to perform their Sami identity and that can preserve and strengthen the Sami culture, for example, social development work or teaching.

In South Sápmi, with a strong presence of Sami history through language and reindeer herding, the influence of the reindeer herding on perceived possibilities and choice is strong. As argued by Ask, a South Sami, on his home place: "Where mother grew up and where I have spent most of my time ... Reindeers mean a lot to me, but I'm not sure what will happen." Yet several argued for the relation between the choices of education, such as teacher training, with specialization in South Sami language, and nursing, and the possibilities for the practicable combinations with reindeer husbandry, being in the mountains, and family and children. Hence, any choices of education and occupation seem clearly linked to thoughts about future residence in the South Sápmi territory, a residence where they can practice their Sami identity both in relation to career choices in combination with being active reindeer herders and maintaining family traditions at the same time. As Embla, a South Sami informant told us, "In the city you don't get the same community ... Far away and desolate here, but also deserted in the city." Dagmar adds to this statement, "We have something unique that not many experience ... We are somewhat shielded, a bit alone, being a bit cool, unlike other places where there are several Sami and more people." Further, four of the South Sami informants spoke about the importance of education at "Samernas Utbildningscentrum in Jokkmokk Sweden" (est. 1942) for safeguarding Sami identity and as an important meeting place and social arena for Sami youth. They said that attending this school is almost a family tradition. The school welcomes students from eighteen years of age from all over the Sápmi. The school offers a basic first year and second year with a specialization, for example, in forms of duodji (handicrafts), reindeer industry, or language studies. In addition to the school, Jokkmokk hosts Ájtte-the principal museum of Sami culture and the 400-year-old Sami winter market, which spans three days in every February. Jokkmokk has long been "a place for trade, gatherings, festivals and meetings between friends" (Ájtte 2017). Brita, a South Sami informant, told me that she appreciated "going to Sami 
school and getting to know other Sami"; Carine reasoned her choice of education as a result of the possibility to immerse oneself in "traditions: what interests me." In addition, the importance of proximity experiences among South Sami youth were highlighted through statements that stressed the importance of Sami socialization and meetings via education, as well as through established meeting places and regular arrangement. Åanghkerenjeeruve (Ankarede) and Plaavere (Blåsjön) were mentioned as important meeting places in the southern part of Sápmi, for example when celebrating midsummer. An analogy is the view of a global sense of place, where places are constructed based on specific constellations of social relationships between people and connections between places. Meeting places like Guovdageaidnu (Kautokeino) Kárásjohka (Karasjok), Snåase (Snåsa), Plassje (Røros), Frööstege (Frostviken) / Åanghkerenjeeruve (Ankarede), and Jokkmokk, are places where family traditions, identitycreating processes, and culture-bearing activities unfold and verify youth Sami identity.

Family and culture-bearing activities were also important among the North Sami youth. John says, "I think I will return to Finnmark if I can get work, I have relatives everywhere in Finnmark, so the whole of Finnmark is home to me." Family ties are also very important to Elen, who wants to stay in Guovdageaidnu (Kautokeino) to be close to her core family, because she is very attached to the place. Per is not certain he will return to his home place (Guovdageaidnu) because "then I have to become a teacher." While he considers teaching as one possibility, his first choice is to be a historical researcher or a biologist, but he said that "then I would most likely be sitting around doing nothing" if he returns. However, other places are increasingly becoming "places of opportunity" for Sami youth. For instant, Romssa (Tromsø) has become a more attractive place to study and live for young Sami who wish to express their Sami identity while feeling free to express other aspects of their identity (see Bjørklund 2016). Romssa (Tromsø) is a bigger place; it is also a Norwegian place with many Sami students and inhabitants. The "city life" of Romssa (Tromsø) acts as an attractor-experiencing the urban as a contrast to the life they now live to "see if it is something for me." Moreover, Jenny says that "it is more open in larger places, like Romssa (Tromsø) and Álttá (Alta)" which means that young people are freer to choose and change salient identity dimensions. John adds, "The romantic image of the Sami's, as living in lavos and wearing traditional clothing every day is difficult." Thus, restrictions posed by thoughts about a "true" Sami identity are experienced as limiting for developing other dimensions of their identity 
that perhaps are not in line with assumptions of what constitutes a Sami. Jenny thinks "we do not need to protect ourselves because our homeland is imprinted in our minds," confirming the symbolizing power and restrictions of a Sami identity per se.

However, particular life modes can also influence young Sami to move to places dominated by traditional identity practices and discourses. Anna, for instance, says, "My education depends on where I want to live, and I want to live in a Sami place, so I cannot pursuit my dream job." Anna has grown up in a place outside Finnmark, dominated by a Norwegian culture. Like many other youth in the North, she has one Sami parent. She moved to Guovdageaidnu (Kautokeino) to attend upper high school because she wanted to learn the language and experience the life in a core Sami village. Today, she says that she wants to stay, and hopes that she will find work there in the future. She is positive about Guovdageaidnu (Kautokeino) and thinks that the village has a lot to offer, but that to realize this value "requires involvement" from the people living there, for example, through different versions of the independent life mode.

While young Sami from inner Finnmark agree that something must be done to develop the places in this region, few of them believe in the ripple effects of resource intensive industries such as mining. One reason is the impact on reindeer herding and/or nature. However, the young Sami from the coastal areas are more positive. For instance, Per thinks that Finnmark needs resource intensive industries and that "we can accommodate such industries. Finnmark is a large county and the reindeer herders have too many animals - there is room for both reindeer herding and other industries." Morten's comments resonate with this when he says, "one or two mines are ok, but mines everywhere, then it becomes..." Jenny thinks "urban Sami" are more accommodating towards new industrial development today because "we are more visible through the arts and traditional and non-traditional handicrafts." Hanna, Anna, John, and Mikkel from the North voice the opinions for those who thinks industrial development is a bad and short-sighted idea. They think that risking nature in such a way conflicts with the Sami identity and way of living. As Hanna puts it: "why open up for mining when we have the most beautiful nature in the world"? She continues, "mining will harm the nature and the reindeer." Anna agrees and says "you have to rethink your possibilities, the value creation potential of our nature and the Sami culture can be realized in a much better way, for example through tourism." Dagmar from the South refers to potential projects on wind power in the South Sami region: "To say that they want to build in our pastureland is the 
same as not wanting reindeer herding." Embla expressed a similar statement: "Wind power/mining destroys more than people realize-we'll be fighting hard to herd reindeer here."

In the North, there are many who are positive to resource intensive industries, and Anna continues by saying "many think that this will bring money and jobs into the community, but I do not. Even though I am not from a family of reindeer herders, I think of them, reindeer herding is close to my heart and those who want to allow resource based industries only think of themselves." Mikkel adds to this by saying "yeah, and the tourists do not travel to see mining." While this may seem straightforward, the reasons for being against resource intensive industries can be more complex; as Jenny says, "they (the Sami and in particular reindeer herders) do not trust companies that only seek profit maximization, and they do not trust the government, so they take a proactive approach and say no." The youth further say that interesting work opportunities such as tourism and cultural entrepreneurship are in direct conflict with resource based development and that such efforts would enhance local value creation without risking nature. One reason for this can be that such work opportunities are seen as based on what the Sami values, i.e., nature, handicrafts, and art. As such, tourism and culture oftentimes represent ways of living that can verify a Sami identity when it is congruent with and supportive of a traditional Sami way of life-as South Sami Embla made a point of saying, Sami related tourism has potential beyond "Santa Claus and the reindeer."

Hence, the Sami youth decisions about returning to their home place can be seen as a trade-off between living a more traditional Sami life shaped by the life modes of self-employment and wage earner, and doing what they most want to do in terms of studies and work. In addition, their experience of Sami identity have the power to shape future decisions about work and housing. Further, their identity can explain an expressed desire to return to their home region, primarily to preserve and develop Sami culture through the language and locales that verify the Sami identity through traditional values and practices.

How Can a Life Mode Approach Explain Preferences and Diversity of Sami Youth Identity?

The Sami people have traditionally been self-employed, engaged in reindeer herding, hunting, fishing, and farming. This life mode is characterized by ownership, control, strong community values, strong network ties, and solidarity ideology (Hørup, 2003; Milroy \& Milroy, 
1992). For Sami youth today, reindeer herding differentiates and represents a Sami life mode, consequently it has strongly shaped their thoughts about what constitutes a Sami identity. Reindeer herding distinguishes the Sami from non-Sami, i.e., both as a cultural practice and as a performance (signs and symbols) that signifies the relationship the Sami people have to nature and in particular to place. Further, the links between reindeer herding practices and identity are more articulated, visible, and acknowledged when the parents are Sami and/or live in core Sami areas, in particular in the South (see Riseth, 2006). In these areas, the imagined life modes of youth are different from, but often supportive of, reindeer herding. This entails visions of combining reindeer herding with other identity creating practices linked to the wage earners life mode. In particular, for the females, the wage earner mode appears as a possibility to combine aspirations for work with their Sami identity in a Sami context. As reindeer herding has become a gendered way of life (it is today considered a male activity), females rarely engage in this type of Sami practice (Kuokkanen, 2009). Instead, they express desires to combine future work with a possibility to stay or return to the home place through a life mode that confirms traditional gendered choices, i.e., the female's desires to become teachers or nurses. This is a life mode that easily combines with a family life and an emerging identity as a mother and wife.

Even though residency for many of the young people in this study is not determined, as it partly depends on life phase and emerging job opportunities, we see clearly that the thoughts Sami youth have about future residence and expressions of what is their home place are related to several factors. For instance, in the South, affiliation, (place) identity, and independent life modes, including factors such as family/relatives, reindeer herding and traditional crafts, and language are important. In addition, places in Sweden where the youth can learn the Sami language shape their thoughts about future residency. Several of the informants from the South want a job in the South Sami district where they can practice their South Sami language skills in a professional context. For the youth from the North, linguistic affiliation is also important for their identity. The difference between north and south is that for the South Sami youth, the Sami language and vocabulary expresses the identity particularly in connection with practising reindeer herding as an independent life mode. For instance, reindeer are marked with colour shades expressed with Sami words and phrases. While the youth from Guovdageaidnu (Kautokeino) reason in much the same way as those from the South Sami areas, the 
majority envision the life mode of wage earners employed in the public sector such as education or social services, simply because the public sector is the largest employer in the north core Sami areas. In addition, working in this sector in core Sami areas gives opportunities for practising a life mode supportive of Sami identity preservation by teaching the language or helping Sami youth. Further, the life mode of wage earner strongly shapes the female youth thoughts about an occupation. For many of the females, a wage earner way of life is viewed as a good way to combine other identities, such as that of a mother, which enables them to achieve a family and work-life balance. In that respect, it is tempting to make a link to the strong and traditional family culture of the Sami; however, this is a traditional choice common amongst female youth in other parts of Norway. For both South and North Sami youth, cultural affinity and safeguarding cultural artifacts are emphasized as necessary and critical for preserving core values and keeping the culture alive.

Further, the strong link between a Sami identity and traditional Sami practices, like reindeer herding in Finnmark, can act as a motivation to relocate for the young wishing for a different way of life. By such thinking and decision making, these Sami youth distance themselves from an essentialist Sami identity and a life mode presenting very strong conventions for action and commitment to traditional values and identity preservation. These youth tend to move to places where they feel more at home performing the multiple identities embedded within their persona, which are often places where the majority culture is Norwegian but with growing Sami communities. Here they can pursue and combine other life modes, for example the career life mode, and perform and express their Sami identity in new ways, for example through making and carrying modern versions of the "Kofta" (traditional Sami costume) and participating in modern cultural practices such as "Sami fashion week." These communities can create the familiarity that is important for their feelings of belonging to an ethnic group while enabling them to break free from perceived constraints of what is a Sami. Moreover, for many young Sami, in particular for those who come from coastal areas in the North and do not speak the language, living in a city where they can express other layers of their Sami identity can reinforce identity. Hence, our informants may vary in their desires for affiliation and language practice, but they are all proud of being a Sami-albeit feeling that their "Sami-ness" is not representative of all parts of the Sápmi area in Norway. 


\section{Conclusions and Implications for Further Research}

Different life modes influence Sami youth reflections on their identity and future preferences. In particular, the findings show that the thoughts that Sami youth have about the future are linked to their thoughts about how they can combine a historical and traditional way of life with their own desires for the future, for example linked to work and/or the ways that they want to perform their Sami identity. The link between a traditional Sami life mode and identity is articulated strongest in core Sami areas and in the South, where youth thoughts about what they can do in the future are restricted by their heritage and the context. Yet, they do not see this as a negative thing; instead, their Sami identity enables them to take on a responsibility for future generations - for example, as keepers of a type of Indigenous knowledge and a culture that they want to preserve and develop through a focus on language and culture. Acting as caretakers of Sami culture is a strong driving force that shapes and creates new expressions of identity in different ways. However, how they choose and desire to do this can create conflicting and competing views about what is a Sami. Some of the young Sami choose to confront traditional expressions of the Sami identity by introducing new expressions in their homeland, using the context to their advantage, while others choose to move to a larger place where it is easier to find room, and acceptance, for other expressions of a Sami identity (see Ashkari, 2005; Kielland, 2017; Nyseth \& Pedersen, 2014).

The youth who want to return to their homeland express an interest in the wage-earning life mode, and also suggest that extending the selfemployed life mode can create new opportunities for work in core Sami areas. They highlight the effect of life modes on the Sami identity, for example through tourism and forms of cultural entrepreneurship that will preserve their culture, and where they can tell their stories. In one way, they are not unlike young people everywhere who have particular self-conceptualizations informing articulated claims and visions that shape how they envision their future based on what they know and want. However, living in a Sami place greatly influences how young Sami negotiate their plans for higher education and future work. The importance of having a Sami future - that is, to be able to use the language and strengthen the Sami culture - is, for many, secondary to dreams about future work such as the life mode of a wage earner, which can be viewed as a supportive life mode to other forms that are traditionally chosen, in particular by Sami females (Hørup, 2003; Kuokkanen, 2009). At the same time, living a life with an articulated Sami identity does not necessarily 
entail living in a Sami place. Sami communities in larger cities provide the familiarity that many young Sami people seek in order to perform their identities and pursue different ways of life more in line with their "true selves," perhaps breaking with aspects of a Sami identity that restricts diversity.

The thoughts and choices youth have about desired ways of life are strongly linked to, and represent, a particular type of knowledge about the Sami territory that influences their identity development. This particularly has important implications for positive perceptions about, and welcoming, new industrial development in Finnmark. One important reason for this is that Sami interaction with nature constitutes an important part of their Sami identity (Selle et al., 2015). The life mode of reindeer herding represents this value and, as such, clashes with stories told regarding previous and believed effects of the industrial activity on the herding landscape. Thus, Sami youth face the prospect of resource intensive industry development with apprehension. Further, the identity constructive power embedded in reindeer herding as a representative of Sami tradition and knowing nature can slow down processes of economic development in already economically vulnerable Sami places. Thus, conflicting identities of what is most important, preservation or development, results in different expectations and beliefs about future industry development in Sami areas that divide young people. In particular, in the North of Norway where the division for or against resource intensive development instills desires for some to move, as they feel they do not fit in with "the Sami majority" (Nystad, 2016). Moreover, it marginalizes what being a Sami can be like through articulations of one "true" Sami identity.

Thus, the findings confirm previous research on ethnic identities and show that being able to speak and/or understand the language, perform cultural practices, and maintain strong family relations contribute to enhanced feelings of belonging to an ethnic group (see for example Phinney, 1990). However, the findings also show that new expressions of being a Sami are being created as young Samis choose other ways of life. While life modes that signify or enable salient Sami values influence how Sami youth express and reflect on their Sami identity and envision opportunities for work and residency, they can also act as a foundation for new expressions of a Sami identity linked to different life modes and types of knowledge. Increased mobility and globalization have perhaps contributed to strengthening a Sami identity through stories about their home place, linking the Sami in time and space. However, globalization can act to leverage the homogeneity embedded in narrow, place-bound, 
and potentially restrictive conceptualizations of what is valid in terms of defining elements of an ethnic identity (Massey, 1991; 2013). Yet, it can as such act to leverage new expressions of being Sami that can contribute to strengthening the Sami identity by reducing the conflict embedded in representations of "one Sami identity."

\section{Limitations and Future Studies}

This study attempts to shed some light on Sami youth experiences of their identity and how this influences their thoughts about their future, in particular in terms of returning to their homeland. The study has some methodological limitations. First, the number of young Sami who were interviewed was small, thus the findings cannot be generalized to a larger population. Second, recruiting informants proved to be more difficult than expected and this narrowed the group, in particular in the southern region, which may have influenced the type and amount of information received and analyzed. Yet, even with the limitations mentioned, we think that the findings can contribute with insights about the interplay between identity, context, and situations that contribute theoretically to literature about Sami youth and identity, while having practical value in terms of the future development of Sami communities.

\section{Authors}

Line Mathisen is senior researcher, Innovation, Industry and Regional Development, at Norut Northern Research Institute, Tromsø, Norway.

Espen Carlsson is senior researcher, Trøndelag R\&D Institute, Norway.

Niels Arvid Sletterød is senior researcher, Trøndelag R\&D Institute, Norway.

\section{Notes}

1. The North Sami territory in Norway covers coastal and inner parts of Finnmark, Troms, and Nordland with areas where the Sami language dominates. The North Sami territory has approximately the same size as the South Sami but with more inhabitants in total (Guovdageaidnu/Kautokeino and Kárásjohka/Karasjok alone have about 3,400 inhabitants).

2. The South Sámi Territory reaches out south from Femunden in Norway and from Idre in Dalalarna in Sweden, via Trollheimen and further north to the southern part of Saltfjellet and to the Ume river in Sweden. Hence, South Sámis inhabit four counties in Norway: Hedmark, South- and North Trøndelag and Nordland: The core areas are Røros, Snåase (Snåsa) and Hattfjelldal: The South Sámi territory has approximately the same size as 
the North Sámi and there are approximately 2000 South Sámi inhabitants in total (Norway and Sweden). In other words, the concentration of South Sámis is sparse (Johansen 2006, 54).

\section{References}

Åhren, C. (2008). Är jag en riktig same? En etnologisk studie av unga samers identitesarbete. Umeå universitet, Umeå.

Ájtte. (2017). Ájtte museum in Jokkmokk - The Sami centre. Retrieved from http://www.ajtte.com/english/ 25.04.2017.

Angell, S. (2009). Being Sami, becoming indigenous. Vocal and musical manifestation of Sami and indigenous movement. (Masters thesis), The Arctic University of Norway, Tromsø.

Arntsen, H. (2013, Lørdag 28 September). Stolte unge sør-Samiske identitesbærere. Sagat, pp. 12-13.

Ashkari, T. (2005). Etnisitet og identitet hos Samisk ungdom i Finnmark: Forståelser og forvaltning. (Post graduate thesis), UiT The Arctic University of Norway, Tromsø.

Aure, M., Abelsen, B., \& Nilsen, T. (2012). Ungdom og Goliat. Unge i Hammerfest, Alta og Honningsvåg om petroleumssektoren som framtidig arbeidsmarked. Retrieved from Alta.

Benyon, D., Smyth, M., O’Neill, S., McCall, R., \& Carroll, F. (2006). The place probe: Exploring a sense of place in real and virtual environments. Presence: Teleoperators and Virtual Environments, 15(6), 668-687.

Bergquist, T. (2004). Självstandighetens livsform(er) och småföretagande - tillämpning og och utveckling av realistiks livsformanalys. (Doktorsavhandling), Karlstad University, Karlstad. (47)

Bishop, E.C., \& Willis, K. (2014). “Without hope everything would be doom and gloom": Young people talk about the importance of hope in their lives. Journal of Youth Studies, 17(6), 778-793. https://doi.org/10.1080/13676261.2013.878788

Bjørklund, I. (2016). "Er ikke blodet mitt bra nok?": Om etniske konstruksjoner og identitetsforvaltning i Sápmi. Nytt Norsk Tidsskrift, 32(01-02), 8-20.

Blix, B.H., Hamran, T., \& Normann, H. K. (2013). Struggles of being and becoming: A dialogical narrative analysis of the life stories of Sami elderly. Journal of Aging Studies, 27(3), 264-275. https://doi.org/10.1016/j.jaging.2013.05.002

Cameron, J. (2005). Focusing on the focus group. Qualitative Research Methods in Human Geography, 2, 116-132.

Castree, N. (2003). Place. Connections and boundaries in an inderdependent world. In S.L. Holloway, S.P. Rice, \& G. Valentine (Eds.), Key concepts in goegraphy. London: Sage.

Eckersley, R. (1999). Dreams and expectations: Young people's expected and preferred futures and their significance for education. Futures, 31(1), 73-90. 
Eikeland, S. (2009). Dette er Snøhvit. Retrieved from Alta

Falch, T., \& Selle, P. (2016). Samisk myndighet og territorialitet. Norsk statsvitenskapelig tidsskrift, 31(01), 4-34.

Glaser, B.G., \& Strauss, A.L. (1967). The discovery of grounded theory. Chicago: Aldine Publi. Co.

Goffman, E. (1978). The presentation of self in everyday life: Harmondsworth.

Heij, J. (2012). The human geography knowledge base. Retrieved from http://geography.ruhosting.nl/geography/index.php?title=Main Page\&oldid=3499\#The Human Geography Knowledge Base

Heikkilä, L. (2006). Reindeer talk - Sami reindeer herding and nature management. (Doctoral), Lapland University, Rovaniemi.

Hilmo, J.V. (2012). Språksamfunn i grenseland. Ein sosiolingvistisk studie av språk og språkoppfatningar i Tydalen. (Master), NTNU, Trondhiem.

Hovland, A. (1999). Moderne urfolk: lokal og etnisk tilhørighet blant samisk ungdom: Norsk institutt for forskning om oppvekst, velferd og aldring.

Højrup, T. (1996). Omkring livsformsanalysens udvikling (Vol. 1): Museum Tusculanum Press.

Højrup, T. (2013). Life mode analyis: The coming into being. http://www.lifemode.eu/ about/Life_Mode_Analysis_- the_coming_into_being.pdf

Højrup, T. (2014). Life-mode analysis: A contextual explanation. In K. Schriewer \& S. C. Sánchez (Eds.), Anthropological perspectives: Tols for the analysis of European societies (pp. 217). Münster: Waxmann Verlag GmbH.

Hørup, T. (2003). State, culture and life-modes the foundations of life-mode analysis. England: Aldershot.

Høst, J. (2010). A neoliberal catch: Access rights and the clash of coastal lifemodes. Paper presented at the World Small-Scale Fisheries Bangkok.

Jakobsen, L., Gonäs, L., \& Karlsson, J. (2006). Life modes and gender in the Swedish public-health sector. In L. Gonäs \& J. C. Karlsson (Eds.), Gender segregation: Divisions of work in post-industrial welfare states (pp. 111). Aldershot: Ashgate.

Janesick, V. (2003). Stretching exercises for qualitative researchers. Thousand Oaks, CA: Sage.

Johansen, I. (2006). "Det er ikke eit museumsspråk - det har noko med framtida og gjera" - ei sosiolingvistisk undersøkning av revitaliseringa av sørsamisk. (Master), NTNU, Trondheim.

Johnsen, K. I. (2016). Land-use conflicts between reindeer husbandry and mineral extraction in Finnmark, Norway: Contested rationalities and the politics of belonging. Polar Geography, 39(1), 58-79. https://doi.org/10.1080/108893 7X.2016.1156181

Kielland, I. M. (2017). Strange encounters in place stories. Social \& Cultural Geography, 18(1), 78-91. https://doi.org/10.1080/14649365.2016.1176242 
Kuokkanen, R. (2009). Indigenous women in traditional economies: The case of Sami reindeer herding. Signs, 34(3), 499-504.

Massey, D. (1991). A global sense of place. In T. Barnes \& D. Gregory (Eds.), Reading human geography. The poetics and politics of inquiry (pp. 313-323). London: Arnold.

Massey, D. (2013). Space, place and gender. John Wiley \& Sons.

Milroy, L., \& Milroy, J. (1992). Social network and social class: Toward an integrated sociolinguistic model. Language in Society, 21(01), 1-26.

Nisbett, R.E., Peng, K., Choi, I., \& Norenzayan, A. (2001). Culture and systems of thought: Holistic versus analytic cognition. Psychological Review, 108(2), 291.

Nordin, Å. (2007). Renskötseln är mitt liv: analys av den samiska renskötselns ekonomiska anpassning: Centrum för samisk forskning, Umeå universitet.

NOU. (2007). Samisk naturbruk og rettssituasjonen fra Hedmark til Troms Bakgrunnsmateriale for Samerettsutvalget. Oslo.

Nyseth, T., \& Pedersen, P. (2014). Urban Sami identities in Scandinavia: Hybridities, ambivalences and cultural innovation. Acta Borealia, 31(2), 131-151. https:// doi.org/10.1080/08003831.2014.967976

Nystad, K. (2016). Sami adolescents pathways to adulthood. (Philosophiae doctor), Universitetet i Oslo, Oslo.

Opdenakker, R. (2006). Advantages and disadvantages of four interview techniques in qualitative research. Paper presented at the Forum Qualitative Sozialforschung/ Forum: Qualitative Social Research.

Pedersen, P., \& Viken, A. (2009). Globalized reinvention of indigenuity. The Riddu Riddu Festival as a tool for ethnic negotiation of place. Place Reinvention: Northern Perspectives, 183.

Phinney, J. S. (1990). Ethnic identity in adolescents and adults: Review of research. PsychologicalBulletin, 108(3),499-514.https://doi.org.10.1037/0033-2909.108.3.499

Phinney, J. S. (2005). Ethnic identity in late modern times: A response to Rattansi and Phoenix. Identity, 5(2), 187-194.

Phinney, J. S., \& Ong, A. D. (2007). Conceptualization and measurement of ethnic identity: Current status and future directions. Journal of Counseling Psychology, 54(3), 271-281. https://doi.org/10.1037/0022-0167.54.3.271

Riseth, J. A. (2006). Sami reindeer herd managers: Why do they stay in a low-profit business? British Food Journal, 108(7), 541-559.

Selle, P., Semb, A.J., \& Strømsnes, K. (2013). Citizenship identity among Norwegian Sami in core Sami areas. Citizenship Studies, 17(6-7), 712-727.

Selle, P., Semb, A.J., Strømsnes, K., \& Nordø, Å.D. (2015). Den Samiske medborgeren. Oslo: Cappelen Damm.

Setten, G. (2013). Til fots - et metodeblikk på landskap og praksis. In A. Førde, B. Kramvig, N. G. Berg, \& B. Dale (Eds.), A finne sted: metodologiske perspektiver i stedsanalyse. Bergen: Fagbokforlaget. 
Twigger-Ross, C.L., \& Uzzell, D.L. (1996). Place and identity processes. Journal of Environmental Psychology, 16(3), 205-220.

Valkonen, J., \& Valkonen, S. (2014). Contesting the nature relations of Sami culture. Acta Borealia, 31(1), 25-40. https://doi.org/10.1080/08003831.2014.905010

Valkonen, S. (2014). The embodied boundaries of ethnicity. European Journal of Cultural Studies, 17(2), 209-224. https://doi.org/10.1177/1367549413508101

Wollan, G. (2004). Landskap som praksis. In G. Setten (Ed.), Det levende landskapet. Festskrift til Michael Jones (pp. 49-66). Trondheim: Tapir Akademiske forlag.

Yuval-Davis, N. (2006). Belonging and the politics of belonging. Patterns of Prejudice, 40(3), 197-214. 